\title{
Kultur in vitro pisang (Musa paradisiaca L.) cv. Kepok Merah untuk mikropropagasi cepat
}

\author{
In vitro culture of banana (Musa paradisiaca L.) cv. Kepok Merah for rapid micropropagation \\ Efah FITRAMALA, Eva KHAERUNISA, Nina Ratna DJUITA, Hadi SUNARSO \& \\ Diah RATNADEWI ${ }^{*}$ \\ ${ }^{*}$ Departemen Biologi, Fakultas Matematika dan Ilmu Pengetahuan Alam, Institur Pertanian Bogor \\ Jalan Agatis Gedung Fakultas Peternakan Wing 1 Lt 5. Kampus IPB Darmaga. Bogor 16680
}

Diterima tanggal 22 September 2015 /disetujui tanggal 15 November 2016

\begin{abstract}
Banana (Musa paradisiaca L) cv. Kepok Merah has a high commercial value as it is used in food industries such as banana chip. Besides, Kepok Merah contains high B-complex vitamins that serve in energy metabolism and in the development of infant brain. The establishment of industrial plantations of this plant has been restricted by the lack of planting materials. This research aimed at ameliorating the capacity of plantlets multiplication up to rooting of this banana in a rapid way through in vitro multiplication techniques. Murashige and Skoog (MS) and Woody Plant (WP) media were used as the basic media. For the initiation stage, the media was fortified with $0.2 \mathrm{mg} / \mathrm{L} \mathrm{IAA}$ and two levels of $B A$ at 3 and $5 \mathrm{mg} / \mathrm{L}$. For shoot multiplication, the concentrations of IAA as well as $B A$ were increased. For rooting, $1 \mathrm{mg} / L$ NAA or IBA was applied. The observations demonstrated that for shoots initiation, both basic media performed good results when enriched with $0.2 \mathrm{mg} / \mathrm{L} \mathrm{IAA}$ and $5 \mathrm{mg} / \mathrm{L} \mathrm{BA}$. The highest rate of shoots multiplication at $6-17$ shoots per explant, was obtained on MS medium added with $0.5 \mathrm{mg} / \mathrm{L} \mathrm{IAA}$ and $5 \mathrm{mg} / \mathrm{L} B A$. NAA at $1 \mathrm{mg} / \mathrm{L}$ in $M S$ medium produced more rooted plantlets, 3 - 16 roots per plantlet, than those of other treatments.
\end{abstract}

[Keywords: Musa paradisiaca cv. Kepok Merah, in vitro micropropagation, scalps.]

\section{Abstrak}

Pisang (Musa paradisiaca L.) kultivar Kepok Merah memiliki nilai komersial yang cukup tinggi yaitu sebagai bahan dalam industri pembuatan keripik pisang. Selain itu, pisang Kepok Merah memiliki kandungan vitamin B kompleks cukup tinggi untuk membantu produksi energi dan pembentukan sel-sel otak pada bayi. Pertanaman pisang ini dalam skala industri terkendala oleh kurangnya ketersediaan sumber benih. Teknik kultur jaringan diharapkan dapat menghasilkan benih secara massal dalam waktu yang relatif singkat. Tujuan dari penelitian ini adalah *) Penulis korespondensi: diahbiologi.ipb@gmail.com meningkatkan keberhasilan multiplikasi tunas in vitro hingga pengakaran tanaman pisang Kepok Merah secara cepat. Pada tahap inisiasi tunas digunakan media dasar Murashige and Skoog (MS) dan Woody Plant (WP), ke dalam media dasar tersebut ditambahkan IAA $0,2 \mathrm{mg} / \mathrm{L}$ dan 2 taraf BA yaitu 3 dan $5 \mathrm{mg} / \mathrm{L}$. Multiplikasi tunas dilakukan pada media dasar yang sama namun dengan taraf konsentrasi IAA serta BA yang ditingkatkan. Tahap perakaran menggunakan media dasar MS dan WP dengan auksin NAA $1 \mathrm{mg} / \mathrm{L}$ atau IBA $1 \mathrm{mg} / \mathrm{L}$. Hasil penelitian menunjukkan bahwa untuk inisiasi tunas, media MS dan WP yang diperkaya dengan IAA 0,2 mg/L dan BA $5 \mathrm{mg} / \mathrm{L}$ sama baiknya. Untuk multiplikasi tunas, media MS dengan IAA $0,5 \mathrm{mg} / \mathrm{L}$ yang dikombinasikan dengan BA $5 \mathrm{mg} / \mathrm{L}$ memberikan jumlah tunas paling banyak, yaitu $6-17$ tunas per eksplan, dan pertumbuhannyapun lebih baik. Pemberian NAA $1 \mathrm{mg} / \mathrm{L}$ pada media MS dapat memberikan lebih banyak tunas yang berakar, dengan jumlah akar 3 - 16 per planlet.

[Kata kunci: Musa paradisiaca cv. Kepok Merah, mikropropagasi in vitro, nodul meristematik.]

\section{Pendahuluan}

Pisang Kepok Merah (Musa paradisiaca) termasuk jenis pisang olahan, yang dikonsumsi setelah diberi perlakuan tambahan. Pisang ini merupakan salah satu jenis buah tropis yang mempunyai potensi cukup tinggi untuk dikembangkan di Indonesia. Permintaan pisang semakin meningkat baik untuk konsumsi pangan maupun untuk bahan baku industri. Pisang mewakili $40-45 \%$ dari produk buah nasional. Tahun 2009 produksi pisang mencapai 6,3 juta ton (Artianingsih, 2012), sedangkan menurut BPS (2013) produksi pisang mencapai 5.359.126 ton pada tahun 2013 .

Pisang kepok merah (kelompok genom ABB) mengandung tiamin (vitamin B1), juga mengandung vitamin B3 dan B6. Menurut Prabantini (2010), berbagai vitamin B kompleks membantu produksi energi dan pembentukan sel-sel otak pada bayi, 
sehingga pisang kepok ini banyak dibutuhkan untuk digunakan sebagai makanan pendamping ASI untuk bayi. Seperti halnya dengan pisang kepok lainnya, Kepok Merah juga lazim digunakan sebagai bahan baku untuk pembuatan keripik (Supriati, 2010). Maka pisang Kepok Merah layak dikembangkan untuk tujuan komersial.

Pengembangan kebun pisang secara komersial memerlukan bahan tanam (benih) dalam jumlah yang besar dan serentak. Tanaman pisang dapat diperbanyak dengan anakan, atau belahan bonggol (bit) yang bermata tunas, namun pengadaan benih secara konvensional seperti itu menghadapi kendala karena jumlah anakan yang dihasilkan sedikit sehingga tidak kunjung dapat memenuhi kebutuhan untuk penanaman komersial skala luas. Teknik kultur jaringan dapat mengatasi masalah ini karena teknik ini memiliki potensi untuk memproduksi benih tanaman secara massal dan dalam waktu yang relatif lebih singkat.

Zat pengatur tumbuh dibutuhkan untuk merangsang pertumbuhan tunas dan akar. Penggunaan zat pengatur tumbuh di dalam kultur jaringan tergantung pada arah pertumbuhan jaringan tanaman yang diinginkan (Lestari, 2011). Jenis sitokinin yang sering dipakai adalah Benzil Adenin (BA), karena efektivitasnya tinggi, harganya murah, dan bisa disterilisasi dengan autoklaf. Supriati (2010) pada pisang kepok Amorang melaporkan bahwa BA $1 \mathrm{mg} / \mathrm{L}$ dalam media $1 / 4 \mathrm{MS}$ paling baik untuk multiplikasi tunas, dan Avivi \& Ikrarwati (2004) pada pisang abaka mendapatkan bahwa BA $5 \mathrm{mg} / \mathrm{L}$ sama baiknya dengan kinetin $7 \mathrm{mg} / \mathrm{L}$ dalam menghasilkan planlet.

Penelitian ini bertujuan meningkatkan multiplikasi tunas dan perakaran pada tanaman pisang Kepok Merah dengan perlakuan auksin yang dipadukan dengan sitokinin dengan konsentrasi yang beragam melalui teknik kultur in vitro.

\section{Bahan dan Metode}

Bahan tanaman yang digunakan adalah tunas-tunas muda yang tumbuh pada bonggol (batang dalam tanah) pisang Kepok Merah. Setelah dibersihkan, bahan tanaman sebesar 1 x $5 \mathrm{~cm}$ direndam dalam akuades steril yang diberi tiga tetes Tween 80 selama satu jam. Selanjutnya, bahan eksplan tersebut disterilisasi berturut-turut dalam fungisida Dithane-M45 $2 \mathrm{~g} / \mathrm{L}$ selama 1 jam, bakterisida Agrept $2 \mathrm{~g} / \mathrm{L}$ selama 1 jam, etanol $70 \%$ selama 1 menit, Bayclin (bahan aktif $\mathrm{NaOCl}$ 5,25\%) 30\% selama 30 menit, dan Bayclin 20\% selama 20 menit. Bilasan dengan akuades steril 3 kali dilakukan di setiap tahap sterilisasi tersebut. Eksplan diisolasi dari bahan tanaman itu, dengan cara mengupas pelepahnya hingga terlihat jaringan kuncup apikal berwarna putih, yang kemudian dibelah dua secara membujur untuk menjadi dua buah eksplan.

Media inisiasi pertunasan yang digunakan adalah media modifikasi dari MS (Murashige \& Skoog, 1962) dan WP (Woody Plant, Lloyd \& McCown, 1981) yang diperkaya dengan glisin $2 \mathrm{mg} / \mathrm{L}$ dan auksin IAA (asam indol asetat) $0,2 \mathrm{mg} / \mathrm{L}$ serta sukrosa $30 \mathrm{~g} / \mathrm{L}$ sebagai media dasar. Dua taraf BA dicobakan untuk menginisiasi pertunasan, yaitu 3 dan $5 \mathrm{mg} / \mathrm{L}$. Perlakuan tersebut dinamakan sebagai MI3, MI5, WI3 dan WI5, yaitu media MS inisiasi dengan konsentrasi BA 3 dan $5 \mathrm{mg} / \mathrm{L}$ untuk MI3 dan MI5, serta media WP inisiasi dengan BA 3 dan $5 \mathrm{mg} / \mathrm{L}$ untuk WI3 dan WI5.

Tunas-tunas muda yang dihasilkan pada tahap inisiasi, dikupas pada bagian yang berwarna kehitaman dan dibelah secara aseptik menjadi dua bagian secara membujur. Selanjutnya bahan tanam itu digunakan sebagai eksplan baru untuk perbanyakan tunas dan ditumbuhkan dalam media tanam baru. Media multiplikasi tunas yang digunakan adalah media MS dan WP yang diberi perlakuan zat pengatur tumbuh yang ditingkatkan kadarnya, yaitu IAA $0,5 \mathrm{mg} / \mathrm{L}$ sebagai media dasar, yang dikombinasikan dengan BA 5 dan $7 \mathrm{mg} / \mathrm{L}$ (disebut sebagai media perbanyakan tunas MS dengan BA 5 dan $7 \mathrm{mg} / \mathrm{L}$ untuk MT5, MT7, dan media WP dengan BA 5 dan $7 \mathrm{mg} / \mathrm{L}$ untuk WT5 dan WT7).

Masing-masing perlakuan ditingkat inisiasi serta tingkat multiplikasi tunas dibuat dalam 10 ulangan. Pengamatan dilakukan hingga terlihat warna hijau pada bagian tunas-tunas yang tumbuh.

Tunas yang dihasilkan dari tahap multiplikasi tunas umumnya belum memiliki akar sehingga tidak mampu mendukung pertumbuhan secara mandiri. Oleh karena itu, tunas tersebut dipilih yang seragam (sekitar $2 \mathrm{~cm}$ ) kemudian dipindahkan ke media perakaran. Media perakaran berupa media semi padat MS dan media WP dengan perlakuan NAA $1 \mathrm{mg} / \mathrm{L}$ atau IBA $1 \mathrm{mg} / \mathrm{L}$ (diberi nama media perakaran: MA1, MA2, WA1 dan WA2).

Kultur dipelihara dalam ruang inkubasi bersuhu 25 $\pm 2{ }^{\circ} \mathrm{C}$ di bawah cahaya lampu TL dengan intensitas cahaya sekitar $20 \mu \mathrm{mol}$ foton $/ \mathrm{m}^{2} /$ detik (setara dengan sekitar 1000 lux), dan fotoperiodisitas 16 jam per hari.

\section{Hasil dan Pembahasan}

\section{Tahap inisiasi dan multiplikasi tunas}

Secara keseluruhan inisiasi tunas terjadi pada semua perlakuan media. Sebagian eksplan dapat tumbuh membentuk tunas langsung, namun sebagian tumbuh melalui scalp (nodul meristematik) terlebih dahulu (Tabel 1). Nodul tersebut berwarna putih kehijauan dan mulai tampak pada minggu ke 5 hingga ke 13 setelah tanam. Nodul tersebut bertambah banyak, yang potensial tumbuh membentuk tunas yang banyak pula; sedangkan tunas tunggal atau tunas yang jumlahnya sedikit, yang tumbuh langsung pada eksplan, tidak meningkat jumlahnya tapi memanjang dengan cepat (Gambar 1). Perlakuan BA $5 \mathrm{mg} / \mathrm{L}$ pada media MS maupun WP memberikan nodul dalam jumlah yang lebih banyak daripada perlakuan BA $3 \mathrm{mg} / \mathrm{L}$. Regenerasi langsung membentuk tunas 
maupun melalui nodul terjadi pada kisaran waktu 7 hingga 21 minggu setelah tanam (MST).

Pada tahap inisiasi ini pertumbuhan tunas serta jumlahnya hingga minggu ke 22 masih rendah. Karena itu, tunas muda yang diperoleh dibelah menjadi dua dan ditanam kembali sebagai eksplan pada media multiplikasi tunas. Pada media dengan perlakuan IAA $0,5 \mathrm{mg} / \mathrm{L}$ dan kombinasinya dengan BA 5 dan $7 \mathrm{mg} / \mathrm{L}$, eksplan generasi kedua ini menghasilkan jumlah tunas lebih banyak dan pertumbuhan tunasnya lebih cepat. Rata-rata jumlah tunas pada media multiplikasi tunas MT5 sebanyak 15,4 dengan jumlah total 123 tunas, sedangkan pada WT5 rata-rata jumlah tunas yang terbentuk sebanyak 9,4 dengan total jumlah tunas 75 . Rata-rata jumlah tunas pada MT7 sebanyak 7,2 dan WT7 sebanyak 5,2. Perlakuan MT7 dan WT7 membentuk nodul meristematik namun hanya sedikit, dan bahkan ada yang tidak membentuk tunas langsung sama sekali. Eksplan pada perlakuan MT5 dan WT5 mampu menumbuhkan tunas pada hari ke 8 setelah tanam.

Waktu yang dibutuhkan untuk pembentukan tunas tersebut lebih cepat jika dibandingkan dengan perlakuan MT7 dan WT7. Waktu tumbuh tunas pada perlakuan WT7 terjadi pada hari ke 14 setelah tanam, disusul oleh MT7 pada hari ke 16 setelah tanam (Tabel 2). Pada pisang Grand Naine, Ahmed et al., (2014) mendapatkan inisiasi tunas paling awal pada hari ke 15 setelah tanam, dengan menggunakan media MS yang dipadukan dengan BA $4 \mathrm{mg} / \mathrm{L}$ dan IAA $2 \mathrm{mg} / \mathrm{L}$. Jumlah kultur yang memberikan tunas sebanyak $80 \%$ pada semua perlakuan, kecuali pada MT7 yang hanya 50\%. Media Woody Plant (WT) dengan 5 atau $7 \mathrm{mg} / \mathrm{L}$ BA lebih banyak menghasilkan tunas yang tumbuh langsung dari eksplan, sedangkan media Murashige dan Skoog (MT) menunjukkan sebaliknya yaitu lebih banyak dari nodul meristematik. Perlakuan MT5 memberikan jumlah tunas paling banyak, diikuti oleh perlakuan WT5, WT7 dan kemudian MT7 (Tabel 2). Pertumbuhan dan perkembangan tunas yang berasal dari nodul meristematik/scalp terlihat lebih lambat (Gambar 2).

Pertumbuhan kultur pada tahap multiplikasi tunas juga dimulai dari pembentukan nodul-nodul meristematik berwarna putih (scalp) yang kemudian menghijau, setelah itu tumbuh membentuk tunas dan daun muda. Eksplan pada perlakuan MT5 dan WT5 mampu membentuk tunas pada hari ke 8 setelah tanam; waktu yang dibutuhkan dalam pembentukan tunas tersebut lebih cepat jika dibandingkan dengan perlakuan MT7 dan WT7. Perlakuan MT7 dan WT7 dapat membentuk nodul namun hanya sedikit, dan sebagian dari nodul tersebut sama sekali tidak menjadi tunas. Hal tersebut kemungkinan karena konsentrasi BA $7 \mathrm{mg} / \mathrm{L}$ terlalu tinggi bagi jaringan tanaman pisang Kepok Merah. Menurut Kusmianto (2008) pemberian sitokinin dengan konsentrasi rendah dapat menginduksi tunas karena kandungan sitokinin endogen sudah mencukupi. Penggunaan BA pada konsentrasi tinggi justru dapat menghambat pembelahan sel yang berdampak pada penghambatan pertumbuhan eksplan. Hal yang sama juga dilaporkan oleh Rahman et al. (2004) bahwa BA 5 mg/L merupakan konsentrasi yang paling baik untuk multiplikasi pisang klon BARI-1. Namun Bhosale et al., (2011) memperoleh multiplikasi tunas yang tinggi pada BA $7 \mathrm{mg} / \mathrm{L}$ pada pisang varietas Basrai, Shrimanti dan Ardhapuri, sedangkan pada konsentrasi BA $9 \mathrm{mg} / \mathrm{L}$ jumlah tunas menurun. Penggunaan sitokinin pada konsentrasi yang terlalu tinggi menyebabkan pertumbuhan tunas tidak normal, pendek-pendek, dan sulit untuk tumbuh memanjang (BIOTROP, 2012). Menurut Kasutjianingati et al., (2011) jumlah mata tunas adventif yang terlalu banyak menyebabkan pertumbuhan tunasnya tertekan. Hal itu dapat disebabkan karena terjadi persaingan dalam penggunaan nutrisi di antara tunas-tunas tersebut. Sipen dan Davey (2012) memperoleh nodul meristematik pada kultur pisang Nangka, Mas, Berangan, dan Awak dari media MS yang mengandung BA $11 \mathrm{mg} / \mathrm{L}$ dan IAA $0,2 \mathrm{mg} / \mathrm{L}$. Kemudian nodulnodul tersebut akan tumbuh memanjang menjadi tunas banyak apabila dipindahkan ke media dengan konsentrasi BA sangat rendah, yaitu $1 \mathrm{mg} / \mathrm{L}$. Pada konsentrasi BA $5-7 \mathrm{mg} / \mathrm{L}$, hanya diperoleh diferensiasi langsung yang tumbuh dari eksplan menjadi tunas. Demikian juga dilaporkan oleh Ramirez-Villalobos \& de Garcia (2008) serta Shirani et al., (2010), bahwa untuk menginduksi pembentukan nodul meristematik diperlukan BA $22-25 \mathrm{mg} / \mathrm{L}$, dengan atau tanpa IAA $0,2 \mathrm{mg} / \mathrm{L}$. Dalam hal ini, dapat diduga bahwa konsentrasi BA yang tinggi mendorong pembentukan nodul meristematik, yang akan tumbuh menjadi tunas apabila konsentrasi BA diturunkan.

\section{Tahap perakaran}

Tunas yang dapat disubkultur ke media perakaran jumlahnya berbeda-beda dari masing-masing perlakuan formulasi media. Tunas yang memenuhi kriteria tinggi tunas lebih dari $2 \mathrm{~cm}$ ditetapkan layak dipindahkan ke medium perakaran. Tunas yang berasal dari nodul meristematik jumlahnya banyak tetapi memerlukan waktu lebih lama untuk pemanjangannya. Oleh karena itu, sampai tahap perakaran, dari perlakuan MT5 hanya diperoleh 5 tunas, dari MT7 5 tunas, dari WT5 8 tunas, dan dari WT7 8 tunas. Persentase tunas berakar tertinggi terdapat pada media MS dengan NAA $1 \mathrm{mg} / \mathrm{L}$ (MA1) sebesar $60 \%$, diikuti dengan media WP dan NAA $1 \mathrm{mg} / \mathrm{L}$ (WA1) sebesar 37,5\%. Persentase kultur berakar pada MA2 (media MS dan IBA $1 \mathrm{mg} / \mathrm{L}$ ) sebesar $20 \%$ dan pada WA2 (media WP dan IBA $1 \mathrm{mg} / \mathrm{L}$ sebesar $25 \%$ (Tabel 3). Waktu yang diperlukan untuk tunas menumbuhkan akar berbedabeda pada setiap perlakuan. Tunas pada MA1 berakar pada hari ke 10 setelah tanam, MA2 pada hari ke 9, WA1 pada hari ke 12, sedangkan WA2 membutuhkan waktu untuk berakar pada hari ke 14 setelah tanam pada media perakaran.

Rata-rata jumlah akar terbanyak terdapat pada perlakuan MA1 yaitu sebesar 8,7. Perlakuan WA1 menunjukkan rata-rata jumlah akar yang cukup banyak 
Tabel 1 Inisiasi dan intensitas pertumbuhan nodul meristematik dan tunas pada tahap inisiasi

Table 1 Scalp initiation and its growth intensity and further development to shoots in the initiation stage

\begin{tabular}{cccc}
\hline Perlakuan & $\begin{array}{c}\text { Inisiasi pembentukan nodul } \\
\text { meristematik (MST) } \\
\text { Treatments }\end{array}$ & $\begin{array}{c}\text { Intensitas pertumbuhan } \\
\text { nodul meristematik } \\
\text { (WAP) }\end{array}$ & $\begin{array}{c}\text { Rerata kisaran jumlah tunas } \\
\text { per eksplan* } \\
\text { Scalp growth intensity }\end{array}$ \\
\hline MI3 & 13 & + & $\begin{array}{c}\text { Range number of shoots per } \\
\text { explant }\end{array}$ \\
MI5 & 6 & +++ & $1-6$ \\
WI3 & 5 & + & $0-1$ \\
WI5 & 5 & +++ & $1-2$ \\
\hline
\end{tabular}

* Diamati pada $20-22$ MST (minggu setelah tanam); $+=1-5$ nodul, $++=6-10$ nodul, $+++\geq 10$ nodul. MI3, MI5 = media dasar inisiasi MS dengan BA 3 dan $5 \mathrm{mg} / \mathrm{L}$; WI3, WI5 = media dasar inisiasi WP dengan BA 3 dan $5 \mathrm{mg} / \mathrm{L}$.

* Observed at $20-22$ weeks after planting $(W A P) ;+=1-5$ scalps, $++=6-10$ scalps, $+++\geq 10$ scalps. MI3, MI5 $=$ basic media $M S$ for initiation with 3 and $5 \mathrm{mg} / \mathrm{L} \mathrm{BA}$; WI3, WI5 = basic media WP for initiation with 3 and $5 \mathrm{mg} / \mathrm{L} \mathrm{BA}$

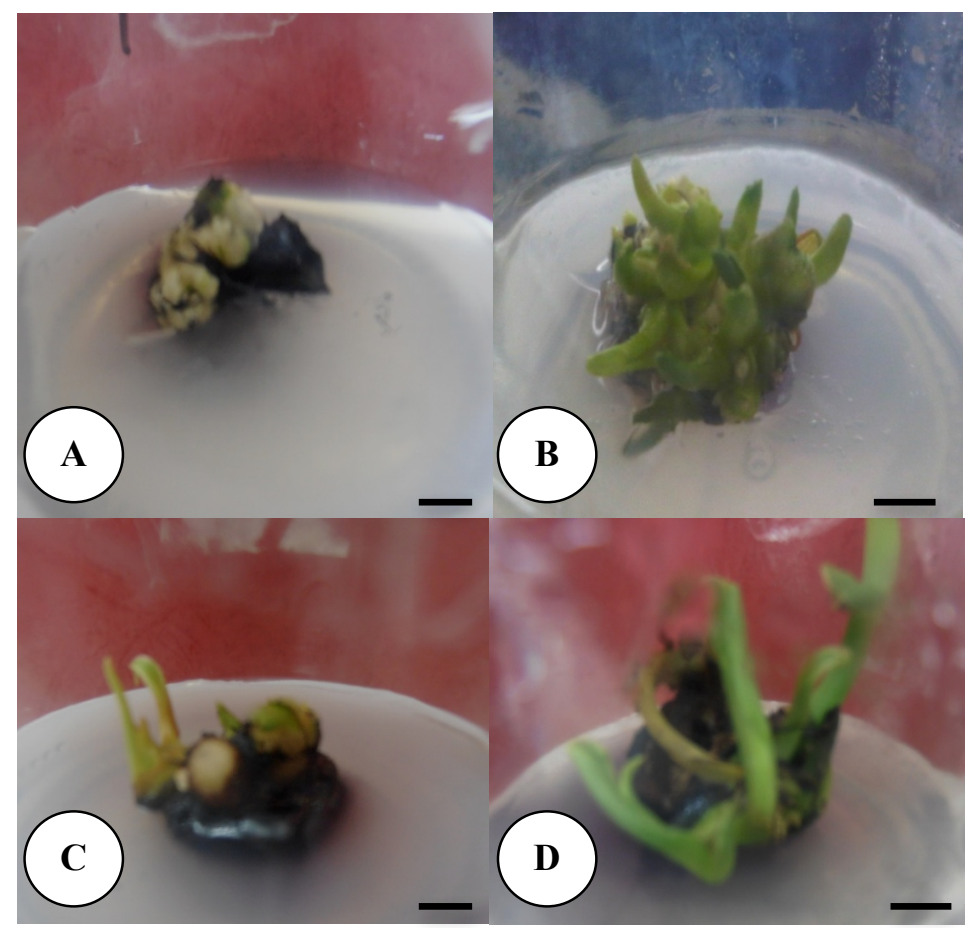

Gambar 1. Inisiasi nodul meristematik (scalp) dan pertumbuhan tunas langsung dari eksplan A) Scalp; B) Tunas yang tumbuh dari scalp; C) dan D) Tunas yang tumbuh langsung dari jaringan eksplan; skala setara dengan $1 \mathrm{~cm}$.

Figure 1. Scalp initiation and direct development of shoots on explants A) Scalp; B) Shoots developed from scalps; C) and D) Shoots directly grew from explant tissue; scale corresponds to $1 \mathrm{~cm}$

setelah MA1 yaitu sebesar 7,3. Perlakuan MA2 memiliki rata-rata jumlah akar sebanyak 6 , sedangkan perlakuan WA2 menunjukkan rata-rata jumlah akar sebanyak 3,5 (Tabel 3).

Jika dilihat dari waktu yang diperlukan untuk berakar media MS lebih cepat menumbuhkan akar daripada media WP. Ditinjau dari jumlah akar yang dihasilkan, NAA dengan konsentrasi $1 \mathrm{mg} / \mathrm{L}$ menghasilkan respons yang lebih baik dibandingkan dengan IBA $1 \mathrm{mg} / \mathrm{L}$. Planlet pada media perakaran dengan NAA $1 \mathrm{mg} / \mathrm{L}$ mampu membentuk akar dengan jumlah yang banyak tetapi akar yang terbentuk pendekpendek (Gambar 3A), sedangkan planlet dengan perlakuan IBA $1 \mathrm{mg} / \mathrm{L}$ membentuk akar sedikit namun panjang (Gambar 3B). Akar terpanjang terdapat pada perlakuan WA2 yaitu sebesar $1,3 \mathrm{~cm}$, diikuti dengan perlakuan MA2 sebesar $1,2 \mathrm{~cm}$, sedangkan MA1 memberikan rerata panjang akar $0,8 \mathrm{~cm}$ dan WA1 sebesar $0,7 \mathrm{~cm}$. 
Tabel 2. Waktu tumbuh tunas dan jumlah tunas pisang Kepok Merah pada tahap multiplikasi

Table 2 Time for shoot initiation and shoots number of Banana Kepok Merah in the multiplication stage

\begin{tabular}{|c|c|c|c|c|c|c|}
\hline \multirow{2}{*}{$\begin{array}{l}\text { Perlakuan } \\
\text { Treatments }\end{array}$} & \multirow{2}{*}{$\begin{array}{l}\text { Waktu inisiasi } \\
\text { pembentukan } \\
\text { tunas (HST) } \\
\text { Initiation time for } \\
\text { shoots formation } \\
(D A P)\end{array}$} & \multirow{2}{*}{$\begin{array}{l}\text { Jumlah kultur } \\
\text { bertunas* } \\
\text { No. of } \\
\text { cultures } \\
\text { having shoots }\end{array}$} & \multirow{2}{*}{$\begin{array}{c}\text { Rerata dan } \\
\text { rentang jumlah } \\
\text { tunas/eksplan } \\
\text { Means \& ranges } \\
\text { of shoots } \\
\text { number/explant }\end{array}$} & \multicolumn{3}{|c|}{$\begin{array}{c}\text { Jumlah total tunas/perlakuan } \\
\text { Total number of shoots/treatment }\end{array}$} \\
\hline & & & & $\begin{array}{l}\text { Langsung dari eksplan } \\
\text { Direct from explant }\end{array}$ & $\begin{array}{l}\text { Asal nodul } \\
\text { From scalp }\end{array}$ & $\begin{array}{l}\text { Jumlah total } \\
\text { Total no. }\end{array}$ \\
\hline MT5 & 8 & 8 & $15,4(6-17)$ & 57 & 66 & 123 \\
\hline MT7 & 16 & 5 & $7,2(3-16)$ & 10 & 26 & 36 \\
\hline WT5 & 8 & 8 & $9,4(2-10)$ & 42 & 33 & 75 \\
\hline WT7 & 14 & 8 & $5,2(2-9)$ & 33 & 9 & 42 \\
\hline
\end{tabular}

$\mathrm{HST}=$ hari setelah tanam.

$D A P=$ days after planting.

* Jumlah total dari 10 kultur per perlakuan. MT5, MT7 = media multiplikasi tunas MS dengan BA 5 dan 7 mg/L; WT5, WT7 = media multiplikasi tunas WP dengan BA 5 dan $7 \mathrm{mg} / \mathrm{L}$.

* Total number from 10 cultures per treatment. MT5, MT7 = multiplication media MS with 5 and 7 mg/L BA; WT5, WT7 = multiplication media WP with 5 and $7 \mathrm{mg} / \mathrm{L} \mathrm{BA}$.
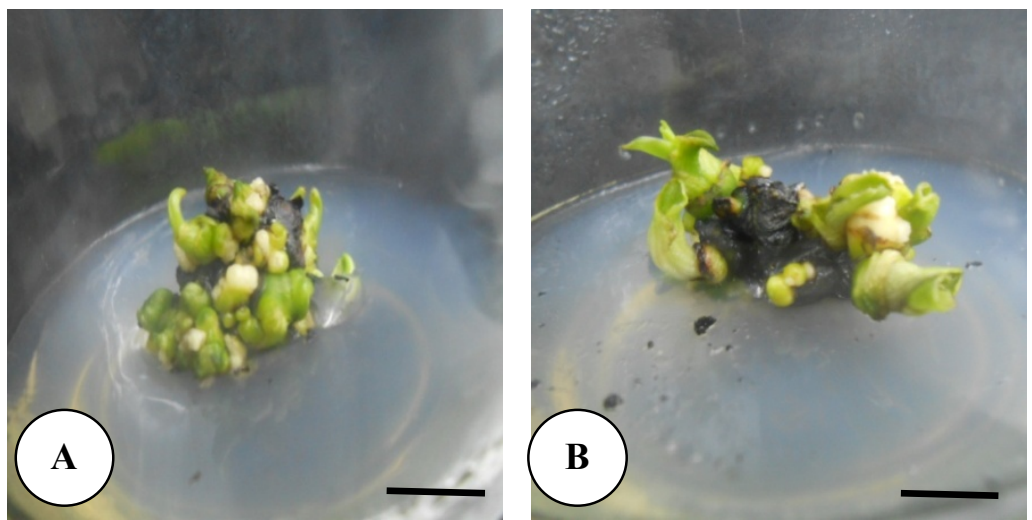

Gambar 2. Pertumbuhan dan perkembangan tunas pada tahap multiplikasi tunas. A) tunas dari nodul meristematik pada MT5 umur 12 MST dan B) tunas langsung dari eksplan pada WT5 umur 6 MST; skala setara dengan $1 \mathrm{~cm}$.

Figure 2. Shoots growth and development in the multiplication stage. Shoots from scalp in MT5 at 12 weeks after planting, and B) shoots developed directly from explant in WT5 at 6 weeks after planting; scale corresponds to $1 \mathrm{~cm}$.

Tabel 3. Jumlah tunas berakar dan panjang akar yang terbentuk

Table 3 Number of rooted shoots and roots length

\begin{tabular}{|c|c|c|c|c|c|}
\hline Perlakuan & Waktu tumbuh akar (HST) & Jumlah tunas berakar* & $\begin{array}{l}\text { Persentase Jumlah } \\
\text { kultur berakar (\%) }\end{array}$ & $\begin{array}{l}\text { Jumlah akar per } \\
\text { planlet }\end{array}$ & $\begin{array}{c}\text { Panjang akar } \\
(\mathrm{cm})\end{array}$ \\
\hline Treatments & $\begin{array}{c}\text { Time of root initiation } \\
(D A P)\end{array}$ & No. of rooted shoots & Rooted cultures (\%) & $\begin{array}{l}\text { No. of roots per } \\
\text { plantlet }\end{array}$ & $\begin{array}{l}\text { Root length } \\
\quad(\mathrm{cm})\end{array}$ \\
\hline MA1 & 10 & $3 / 5$ & 60 & $8,7(3-16)$ & $0,8(0,2-2,1)$ \\
\hline MA2 & 9 & $1 / 5$ & 20 & $1,2(0-6)$ & $1,2(0,5-2,6)$ \\
\hline WA1 & 12 & $3 / 8$ & 37,5 & $7,3(3-10)$ & $0,7(0,4-1,7)$ \\
\hline WA2 & 14 & $2 / 8$ & 25 & $3,5(2-5)$ & $1,3(0,3-3,2)$ \\
\hline
\end{tabular}

HST $=$ hari setelah tanam. Diamati pada 12 minggu setelah tanam.

$D A P=$ days after planting. Observed at 12 weeks after planting.

* Berdasarkan jumlah tunas yang tersedia untuk tahap perakaran. MA1 = media perakaran MS dengan NAA 1 mg/L; MA2 = media MS dengan IBA $1 \mathrm{mg} / \mathrm{L}$; WA1 = media WP dengan NAA $1 \mathrm{mg} / \mathrm{L}$; WA2 = media WP dengan IBA $1 \mathrm{mg} / \mathrm{L}$.

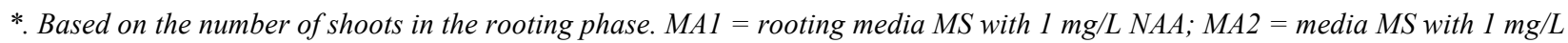
$I B A ; W A 1=$ media $W P$ with $1 \mathrm{mg} / L \mathrm{NAA}$; WA2 = media $W P$ with $1 \mathrm{mg} / \mathrm{L} I B$ 

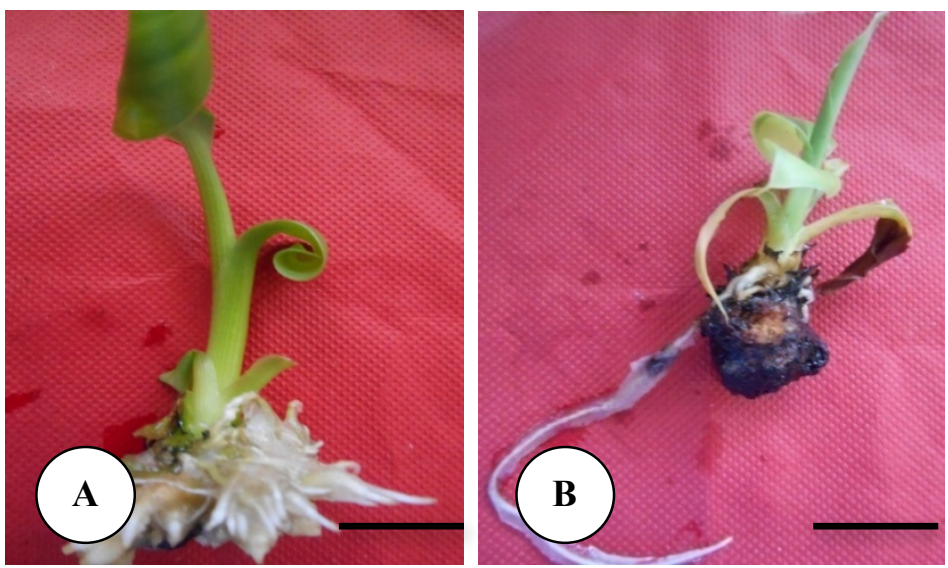

Gambar 3. Penampilan akar pada planlet pisang Kepok Merah umur 12 minggu setelah tanam di media perakaran. Perlakuan MA1 (A) dan perlakuan MA2 (B). Skala setara $1 \mathrm{~cm}$.

Figure 3. Roots performance on Kepok Merah plantlets at 12 weeks after planting on the rooting media. Treatment MA1 (A) and treatment MA2 (B). Scale corresponds to $1 \mathrm{~cm}$.

Berdasarkan rata-rata jumlah akar dan rata-rata panjang akar, zat pengatur tumbuh yang cocok untuk pertumbuhan akar pada planlet pisang Kepok Merah adalah NAA dengan konsentrasi $1 \mathrm{mg} / \mathrm{L}$. Shofiyani dan Budi (2011) melaporkan dalam penelitiannya bahwa NAA 0,4 dan $0,5 \mathrm{mg} / \mathrm{L}$ memberikan jumlah akar tertinggi pada pisang Mas yaitu sebanyak 3,2 akar. Ahmed et al., (2014) dengan pisang cv. Grand Naine memperoleh perakaran paling baik pada media $1 / 2 \mathrm{MS}$ yang mengandung IBA $1 \mathrm{mg} / \mathrm{L}$ dan arang aktif. Planlet berakar yang dihasilkan dari penelitian ini berhasil diaklimatisasi dan ditanam di lapangan.

\section{Kesimpulan}

Mikropropagasi pisang Kepok Merah berhasil dilakukan dengan menggunakan media MS dengan perlakuan zat pengatur tumbuh auksin yang dikombinasikan dengan sitokinin. Tahap inisiasi tunas dapat dilakukan pada media MS atau WP dengan penambahan IAA $0,2 \mathrm{mg} / \mathrm{L}$ dan BA $5 \mathrm{mg} / \mathrm{L}$.

Untuk multiplikasi tunas, media MS dengan IAA $0,5 \mathrm{mg} / \mathrm{L}$ dan BA $5 \mathrm{mg} / \mathrm{L}$ memberikan hasil yang lebih baik dalam perbanyakan tunas dan pemanjangannya, dengan jumlah 6 - 17 tunas per eksplan.

Dalam 10 hari setelah tanam, media MS mampu memacu pertumbuhan akar, dan bersama dengan NAA $1 \mathrm{mg} / \mathrm{L}$ jumlah akar yang terbentuk sebanyak 3- 16 akar per planlet.

\section{Daftar Pustaka}

Ahmed S, A Sharma, AK Singh, VK Wali \& P Kumari (2014). In vitro multiplication of banana (Musa sp.) cv. Grand Naine. Afr J Biotechnol 13(27), 26962703.

Artianingsih S (2012). 19 Peluang Investasi Kayu, Tanaman Perkebunan, dan Tanaman Buah. Jakarta, Agromedia.
Avivi S \& Ikrarwati (2004). Mikropropagasi pisang abaca (Musa textilis Nee) melalui teknik kultur jaringan. Ilmu Pertan 11(2), 27-34.

Bhosale UP, SV Dubhashi, NS Mali \& HP Rathod (2011). In vitro shoot multiplication in different species of banana. Asian J Plant Sci Res 1(3), 2327.

BIOTROP. Biologi Tropika (2012). Produksi bibit tanaman dengan menggunakan teknik kultur jaringan. Bogor, SEAMEO BIOTROP.

BPS. Badan Pusat Statistik (2013). Produksi Buah dan Sayur. Diunduh dari http://www.bps.go.id [6 Maret 2014].

Kasutjianingati R Poerwanto, Widodo, N Khumaida, \& D Efendi (2011). Pengaruh media induksi terhadap multiplikasi tunas dan pertumbuhan planlet pisang rajabulu (AAB) dan pisang tanduk (AAB) pada berbagai media multiplikasi. J Agron Indonesia 39, 180-187.

Kusmianto (2008). Pengaruh thidiazuron dan BA terhadap pertumbuhan plb dan tunas Dendrobium atennatum Lindl. (Skripsi). Depok, Universitas Indonesia,

Lestari EG (2011). Peranan zat pengatur tumbuh dalam perbanyakan tanaman melalui kultur jaringan. $J$ Agrobiogen 7(1), 63-68.

Lloyd G \& B McCown (1981). Commercially feasible micropropagation of mountain laurel, Kalmia latifolia by use of shoot tip culture. Comb Proc Intl Plant Prop Soc 30, 421-427.

Murashige T \& F Skoog (1962). A revised medium for rapid growth and bio assasys with tobacco tissue culture. Physiol Plant 15, 473-497.

Prabantini D (2010). A to Z Makanan Pendamping Asi. Yogyakarta, Andi Offset. 
Rahman MZ, KM Nasiruddin, MA Amin, \& MN Islam (2004). In vitro response and shoot multiplication of banana with BA and NAA. Asian J of Plant Sci 3, 406-409.

Ramirez-Villalobos M \& E de Garcia (2008). Obtainment of embryogenic cell suspensions from scalps of the banana CIEN-BTA-03 (Musa sp., AAAA) and regeneration of the plants. Electron $J$ Biotechnol 11(5). Special Issue.

Shirani S, M Sariah, W Zakaria, \& M Maziah (2010). Scalp induction rate responses to cytokinins on proliferating shoot-tips of banana cultivars (Musa spp.). Amer J of Agric Biol Sci 5 (2), 128-134.
Shofiyani A \& GP Budi (2011). Upaya pengembangan tanaman Pisang Mas (Musa paradisiaca L) bebas patogen melalui metode kultur meristem. Agritech $1(8), 46-66$.

Sipen P \& MR Davey (2012). Effects of $\mathrm{N}^{6}$ benzylaminopurine and indole acetic acid on in vitroshoot multiplication, nodule-like meristem proliferation and plant regeneration of Malaysian bananas (Musa spp.). Trop Life Sci Res 23(2), 67-80.

Supriati Y (2010). Efisiensi mikropropagasi pisang kapok amorang melalui modifikasi formula media dan temperatur. J Agrobiogen 6, 91-100. 